\title{
Influence of Human Papillomavirus Infection on the Natural History of Cervical Intraepithelial Neoplasia 1: A Meta-Analysis
}

\author{
Mingzhu Liu, ${ }^{1,2}$ Xiaolong Yan, ${ }^{1,2}$ Mei Zhang, ${ }^{1,2}$ Xiaoju Li, ${ }^{1,2}$ \\ Shugang $\mathrm{Li}^{1,2}$ and Mingxia Jing ${ }^{1,2}$ \\ ${ }^{1}$ Department of Public Health, Shihezi University School of Medicine, Shihezi, Xinjiang, China \\ ${ }^{2}$ The Key Laboratories for Xinjiang Endemic and Ethnic Diseases, Shihezi University, Shihezi, Xinjiang, China \\ Correspondence should be addressed to Shugang Li; lishugang@ymail.com and Mingxia Jing; jingmingxia126@126.com
}

Received 10 February 2017; Revised 13 April 2017; Accepted 8 May 2017; Published 24 July 2017

Academic Editor: Myong Cheol Lim

Copyright (C) 2017 Mingzhu Liu et al. This is an open access article distributed under the Creative Commons Attribution License, which permits unrestricted use, distribution, and reproduction in any medium, provided the original work is properly cited.

Objective. To provide a scientific basis for the prevention and treatment of cervical intraepithelial neoplasia grade 1 (CIN1). This study evaluated the impact of human papillomavirus (HPV) infection on the natural history of CIN1. Methods. Electronic databases of Cochrane Library, EMBASE, PubMed, CNKI, CBM, and Wanfang were searched in April 2016. The eligibility criteria were documented by Preferred Reporting Items for Systematic Reviews and Meta-Analyses (PRISMA). We used the Newcastle-Ottawa scale (NOS) to assess study quality. Results. Thirty-eight studies out of 3,246 identified papers were eligible for inclusion. The risk of CIN1 progression (relative risk [RR]: 3.04; 95\% confidence interval [CI]: 2.41-3.83; $P<0.00001$ ) and persistence (RR: 1.48; 95\% CI: 1.17-1.87; $P=0.001$ ) was higher in the HPV-positive group than HPV-negative group. Specifically, the risk of CIN1 progression (RR: 13.91; 95\% CI: 3.46-55.90; $P=0.000$ ) was higher among persistent high-risk HPV-positive patients and the ratio of CIN1 regression (RR: 0.65; 95\% CI: 0.59-0.71; P < 0.00001) was lower in the HPV-positive group than HPV-negative group. Conclusion. HPV infection resulted in an increased risk of CIN1 progression and decreased disease reversibility. Persistent high-risk HPV infection resulted in a further increased risk of CIN1 progression.

\section{Introduction}

Cervical intraepithelial neoplasia grade 1 (CIN1) is a precancerous lesion closely related to cervical cancer and characterized by a shorter and less observable clinical course. There is no consensus for intervention and treatment of CIN1, and there are currently no clear markers to predict disease progression and regression [1]. Human papillomavirus (HPV) is a major causative pathogen of reproductive tract infections and can induce the immortalization of normal cells, which precedes their malignant transformation. Approximately 90\% of CIN cases and over $99 \%$ of cervical cancer cases occur in HPV-positive patients [2]; therefore, HPV testing has become a major component of cervical disease screening, diagnosis, and follow-up. The association between CIN1 and HPV remains controversial. The results of several studies suggest that CIN1 is mainly caused by low-risk HPV infection [3-5]. However, there is also evidence that high-risk HPV is strongly associated with CIN1 [6,7]. Differences in the risk of
HPV infection and CIN1 disease outcome $[8,9]$ may be due to regional differences in populations. Furthermore, there are scarce independent systematic reviews on the effects of HPV infection and CIN1. This study evaluated the impact of HPV infection on the natural history of CIN1 by conducting a literature review in order to provide a scientific basis for the prevention and treatment of CIN1.

\section{Methods}

2.1. Electronic Literature Databases. A systematic search was conducted using the Cochrane Library, Excerpta Medica database (EMBASE), PubMed, China National Knowledge Infrastructure (CNKI), Chinese Biomedical Literature Database (CBM), and the Wan fang Data. The literature search was performed on April 20, 2016. The PICOS items were identified (see Appendix 1 in Supplementary Material available online at https://doi.org/10.1155/2017/8971059) in this study as follows: $\mathrm{P}$, cervical intraepithelial neoplasia grade 
1 (CIN1); I, HPV positivity; C, HPV negative; O, the relative risk (RR) of progression, persistence, and regression of CIN1 in HPV-positive and HPV-negative patients being compared; $S$, retrospective studies and prospective studies. The search strategies were determined (the specific search strategy is described in Appendix 2) before the study. The MESH search terms for PubMed included the following: ("Squamous Intraepithelial Lesions of the Cervix" [MeSH] OR low-grade squamous intraepithelial lesion OR mild cervical dysplasia OR CIN1 OR mild Cervical Intraepithelial Neoplasia) AND ("Human Papillomavirus DNA Tests"[MeSH] OR human papillomavirus detected OR human papillomavirus test OR human papillomavirus infection) AND (Cohort Study OR follow up).

2.2. Inclusion and Exclusion Criteria. We systematically reviewed published studies according to the following inclusion criteria: studies examining the impact of HPV infection on the natural history of CIN1 disease; studies including at least HPV-negative and HPV-positive; results at the start and end of follow-up including cervical histology or cytology, a diagnosis consistent with the CIN classification system or atypical hyperplasia (dysplasia) and the carcinoma in situ (CIS) classification system; patients diagnosed with CIN1 who did not undergo interventions including cryosurgery, electrocoagulation therapy, laser therapy, microwave therapy, cold knife conization, loop electrosurgical excision procedure, and trachelectomy; follow-up observation for at least 6 months; complete information so that each document contained sufficient information to calculate statistical indicators of relative risk (RR) or $95 \%$ confidence intervals (CIs). The exclusion criteria were as follows: studies that did not meet the inclusion criteria, literature reviews, the absence of a control group, and duplicate publications. We also excluded papers with incomplete initial data.

2.3. Quality Assessment. The Newcastle-Ottawa scale (NOS), recognized as a good study quality assessment tool, was used to assess the quality of the studies identified in our literature search (see Appendix 3). The evaluation system included eight literature evaluation entries for a total of nine possible points [44], including the selection of the study population, comparability, exposure assessment, and the results of the evaluation. The NOS scale validity rating criteria are as follows: $8-9$, high quality; $6-7$, medium quality; $<5$, low quality.

2.4. Data Collection. Two authors (Mingzhu Liu and Xiaolong Yan) independently extracted data and crosschecked their data after aggregating the results. Disagreements were resolved by discussion with Professor Mingxia Jing. Data were collected at the start of the study, including basic information, background and characteristics of the research object, and disease diagnosis and evolution. This information is presented in Table 1 .

2.5. Data Analysis. Thirty-eight articles were analyzed using RevMan 5.0 (Cochrane systems IMS) and Stata 12.0 (Stata
Corp, College Station, Texas, TX, USA). To assess the heterogeneity among studies, we calculated the $I^{2}$ index. Low and high levels of heterogeneity were considered as $I^{2} \leq$ $50 \%$ and $>50 \%$, respectively. We use a fixed model on the conditions of $P>0.05$ and $I^{2} \leq 50 \%$. We use a randomized model on the conditions of $P<0.05$ or $I^{2}>50 \%$. Combined effects were estimated as relative risk (RR) values with 95\% confidence intervals (CIs). All reported $P$ values were two-sided, and a significance level of 0.05 was used. Subgroup analyses were also performed by HPV type (highrisk HPV and low-risk HPV), study design (retrospective and prospective studies), regional population distribution (Asian, European, and American populations), sample size $(<100$ cases, $100-500$ cases, and $>500$ cases), and follow-up time (6-18 months, 18-24 months, and $>24$ months). Sensitivity analyses were performed using Stata 12.0.

\section{Results}

3.1. Search Result. Figure 1 shows the study selection process. Initially, 3,246 articles were included in our search strategy. A total of 38 articles, including 9,758 patient cases, were finally included in the analysis, based on the inclusion and exclusion criteria. A total of 27 studies assessed regression of CIN1 to a normal status. Twenty-five studies examined persistent CIN1 and 36 articles evaluated the progression from CIN1 to highgrade cervical intraepithelial neoplasia and cervical cancer (CIN2+).

3.2. Basic Characteristics and Quality Assessment of the Included Studies. The basic features of the 38 studies included in this meta-analysis are listed in Table 1 . The studies spanned a period of 30 years (1986 to 2016) and included 22 prospective and 16 retrospective studies. The study sample sizes ranged from 29 [41] to 2,009 [30] cases. Twenty-seven studies reported median/mean ages, ranging from 16 to 76 years. The mean follow-up time ranged from 6 to 96 months. The studies included Asian (16 studies), European (14 studies), and American (8 studies) populations. Thirty-eight studies had quality ratings between 7 and 9 points, with an average of 7.84 points. Twenty-eight articles had quality scores $\geq 8$ points, corresponding to high-quality research, while 10 articles were of medium quality.

\section{Results of the Meta-Analysis}

4.1. The Influence of HPV Infection on the Outcome of CIN1 Lesions. A total of 38 studies were included in this study, and of these, 34 estimated the impact of HPV infection on the progression of CIN1 lesions; pooled analysis showed that the risk of CIN1 disease progression was 3.04-fold higher in the $\mathrm{HPV}$-positive group than in the HPV-negative group (95\% CI: 2.41-3.83; $Z=6.28 ; P<0.00001$ ), with low heterogeneity $\left(P=0.01 ; I^{2}=39 \%\right.$; Figure 2(a)). Twenty-three studies estimated the impact of HPV infection on the persistence of CIN1 lesions; pooled analysis showed that the risk of CIN1 disease persistence was 1.48-fold higher in the HPVpositive group than in the HPV-negative group (95\% CI: $1.17-1.87 ; Z=3.25 ; P=0.001$ ), with significant heterogeneity 
TABLE 1: Basic characteristics and quality assessment of included studies.

\begin{tabular}{|c|c|c|c|c|c|c|c|c|}
\hline Study & Design & $\begin{array}{c}\text { Age } \\
\text { (years) }\end{array}$ & $\begin{array}{c}\text { Region } \\
\text { (subgroup) }\end{array}$ & HPV type & $\begin{array}{c}\text { HPV } \\
\text { infection } \\
\text { time }\end{array}$ & Indexes & $\begin{array}{l}\text { Follow-up } \\
\text { time } \\
\text { (months) }\end{array}$ & $\begin{array}{l}\text { Quality } \\
\text { rating }\end{array}$ \\
\hline Sagasta et al. (2016) [10] & Prospective & $33 \pm 10$ & $\begin{array}{c}\text { Spain } \\
\text { (Europe) }\end{array}$ & HR-HPV & NR & (1)(2) (3) & 28 & 8 \\
\hline $\begin{array}{l}\text { Veijalainen et al. (2015) } \\
\text { [11] }\end{array}$ & Retrospective & 40.4 & $\begin{array}{l}\text { Finland } \\
\text { (Europe) }\end{array}$ & HR-HPV & NR & (1) & 96 & 8 \\
\hline He et al. (2015) [12] & Retrospective & $35 \pm 16.93$ & China (Asia) & HR-HPV & NR & (1)(2) (3) & $15(8-24)$ & 9 \\
\hline Zhou et al. (2015) [13] & Prospective & $37.57 \pm 9.12$ & China (Asia) & HR-HPV & NR & (3) & 24 & 7 \\
\hline Mou et al. (2014) [14] & Retrospective & $38.18 \pm 4.26$ & China (Asia) & NR & NR & (1) (2) (3) & 36 & 7 \\
\hline $\begin{array}{l}\text { Siriaunkgul et al. (2014) } \\
\text { [15] }\end{array}$ & Prospective & 46.6 & $\begin{array}{l}\text { Thailand } \\
\text { (Asia) }\end{array}$ & NR & NR & (1)(2) (3) & 24 & 8 \\
\hline Hu et al. (2014) [16] & Prospective & $30-59$ & China (Asia) & HR-HPV & $\begin{array}{l}\text { Transient } \\
\text { Persistent }\end{array}$ & $\begin{array}{l}\text { (1) (2) (3) } \\
\text { (1) (2) (3) }\end{array}$ & 24 & 9 \\
\hline Jiang (2013) [17] & Retrospective & $39.16 \pm 8.97$ & China (Asia) & HR-HPV & NR & (1) (2) (3) & 24 & 8 \\
\hline $\begin{array}{l}\text { Waldstrøm et al. (2013) } \\
\text { [18] }\end{array}$ & Prospective & 32.3 & $\begin{array}{l}\text { Denmark } \\
\text { (Europe) }\end{array}$ & NR & NR & (1)(2) (3) & 60 & 8 \\
\hline Katki et al. (2013) [19] & Prospective & $30-64$ & $\begin{array}{l}\text { United States } \\
\text { (America) }\end{array}$ & NR & NR & (1)(2)(3) & 60 & 8 \\
\hline Byun et al. (2013) [20] & Prospective & 46 & Korea (Asia) & HR-HPV & NR & (1) & 8 & 8 \\
\hline Liao et al. (2013) [21] & Prospective & $30-49$ & China (Asia) & HR-HPV & NR & (1) & 36 & 8 \\
\hline Li et al. (2013) [22] & Prospective & 38 & China (Asia) & HR-HPV & NR & (3) & 6 & 8 \\
\hline Wang et al. (2012) [6] & Retrospective & $35.4(20-53)$ & China (Asia) & HR-HPV & Persistent & (1) & $18.6(8-24)$ & 9 \\
\hline Huang et al. (2012) [23] & Retrospective & $30(22-70)$ & China (Asia) & HR-HPV & NR & (1) & 24 & 7 \\
\hline Bowring et al. (2012) [24] & Prospective & $36.8 \pm 10.2$ & $\begin{array}{l}\text { Britain } \\
\text { (Europe) }\end{array}$ & HR-HPV & NR & (1)(2) (3) & 12 & 8 \\
\hline $\begin{array}{l}\text { Jakobsson et al. (2012) } \\
\text { [25] }\end{array}$ & Retrospective & 34 & $\begin{array}{l}\text { Finland } \\
\text { (Europe) }\end{array}$ & HR-HPV & NR & (1) & 6 & 8 \\
\hline Ozaki et al. (2011) [26] & Prospective & 39 & Japan (Asia) & NR & NR & (1) & 17 & 7 \\
\hline Li and Yang (2011) [5] & Prospective & $30 \pm 2.32$ & China (Asia) & $\begin{array}{l}\text { HR-HPV } \\
\text { LR-HPV }\end{array}$ & NR & $\begin{array}{l}\text { (1) (2) } 3 \\
\text { (2) } 3\end{array}$ & 6 & 8 \\
\hline $\begin{array}{l}\text { Gonzalez-Bosquet et al. } \\
\text { (2010) [27] }\end{array}$ & Prospective & 32.25 & $\begin{array}{l}\text { Germany } \\
\text { (Europe) }\end{array}$ & HR-HPV & NR & (1) & 25 & 7 \\
\hline $\begin{array}{l}\text { Waldstrøm and Ømskov } \\
\text { (2010) [28] }\end{array}$ & Retrospective & 32 & $\begin{array}{l}\text { Denmark } \\
\text { (Europe) }\end{array}$ & NR & NR & (1)(2) (3) & 36 & 8 \\
\hline Heider et al. (2010) [29] & Retrospective & 33 & $\begin{array}{l}\text { United States } \\
\text { (America) }\end{array}$ & HR-HPV & NR & (1)(2)(3) & 34 & 9 \\
\hline Cotton et al. (2010) [30] & Prospective & $20-59$ & $\begin{array}{l}\text { Britain } \\
\text { (Europe) }\end{array}$ & HR-HPV & NR & (1) & 36 & 8 \\
\hline Thrall et al. (2009) [7] & Prospective & $\geq 30$ & $\begin{array}{l}\text { United States } \\
\text { (America) }\end{array}$ & HR-HPV & NR & (1)(2) (3) & 24 & 9 \\
\hline Liao (2008) [31] & Prospective & $30-49$ & China (Asia) & HR-HPV & NR & (3) & 24 & 7 \\
\hline Gong (2007) [1] & Prospective & $38.37 \pm 5.26$ & China (Asia) & HR-HPV & $\begin{array}{l}\text { Transient } \\
\text { Persistent }\end{array}$ & $\begin{array}{l}\text { (1) (2) (3) } \\
\text { (1) (2) (3) }\end{array}$ & 24 & 7 \\
\hline $\begin{array}{l}\text { Luis Ferreira Santos et al. } \\
(2006)[32]\end{array}$ & Prospective & $31(16-63)$ & $\begin{array}{l}\text { United States } \\
\text { (America) }\end{array}$ & NR & NR & (1)(2) (3) & 12 & 8 \\
\hline $\begin{array}{l}\text { Tarkkanen et al. (2006) } \\
\text { [33] }\end{array}$ & Prospective & $35(20-60)$ & $\begin{array}{l}\text { Finland } \\
\text { (Europe) }\end{array}$ & NR & NR & (1) & 6 & 7 \\
\hline Song et al. (2006) [34] & Retrospective & 38 & Korea (Asia) & NR & NR & (1) (2) (3) & 24 & 8 \\
\hline Clavel et al. (2005) [35] & Retrospective & 30 & $\begin{array}{l}\text { France } \\
\text { (Europe) }\end{array}$ & HR-HPV & NR & (1)(2) (3) & 24 & 8 \\
\hline
\end{tabular}


TABLE 1: Continued.

\begin{tabular}{|c|c|c|c|c|c|c|c|c|}
\hline Study & Design & $\begin{array}{c}\text { Age } \\
\text { (years) }\end{array}$ & $\begin{array}{c}\text { Region } \\
\text { (subgroup) }\end{array}$ & HPV type & $\begin{array}{c}\text { HPV } \\
\text { infection } \\
\text { time }\end{array}$ & Indexes & $\begin{array}{l}\text { Follow-up } \\
\text { time } \\
\text { (months) }\end{array}$ & $\begin{array}{l}\text { Quality } \\
\text { rating }\end{array}$ \\
\hline \multirow[t]{2}{*}{ Massad et al. (2004) [36] } & \multirow{2}{*}{ Prospective } & \multirow{2}{*}{37.4} & \multirow{2}{*}{$\begin{array}{l}\text { United States } \\
\text { (America) }\end{array}$} & HR-HPV & NR & (1) (2) (3) & \multirow{2}{*}{90} & \multirow[t]{2}{*}{8} \\
\hline & & & & LR-HPV & NR & (1)(2) (3) & & \\
\hline $\begin{array}{l}\text { Sastre-Garau et al. } \\
(2004)[37]\end{array}$ & Retrospective & 31 & $\begin{array}{l}\text { France } \\
\text { (Europe) }\end{array}$ & HR-HPV & NR & (1) (3) & 24 & 8 \\
\hline $\begin{array}{l}\text { Alameda et al. (2004) } \\
\text { [38] }\end{array}$ & Retrospective & $25-45$ & $\begin{array}{l}\text { Spain } \\
\text { (Europe) }\end{array}$ & $\mathrm{HPV}$ & NR & (2) (3) & 24 & 7 \\
\hline \multirow{2}{*}{$\begin{array}{l}\text { Schlecht et al. (2003) } \\
\text { [39] }\end{array}$} & \multirow{2}{*}{ Retrospective } & \multirow{2}{*}{$16-65$} & \multirow{2}{*}{$\begin{array}{c}\text { Brazil } \\
\text { (America) }\end{array}$} & HR-HPV & NR & (1) & \multirow{2}{*}{53.3} & \multirow{2}{*}{8} \\
\hline & & & & LR-HPV & NR & (1) & & \\
\hline $\begin{array}{l}\text { Denise Zielinski et al. } \\
\text { (2001) [40] }\end{array}$ & Retrospective & $40.5(20-76)$ & $\begin{array}{l}\text { Holland } \\
\text { (Europe) }\end{array}$ & HR-HPV & NR & (1) (2) (3) & $16.8(0-54)$ & 8 \\
\hline $\begin{array}{l}\text { Matsuura et al. (1997) } \\
\text { [41] }\end{array}$ & Prospective & NR & $\begin{array}{l}\text { United States } \\
\text { (America) }\end{array}$ & NR & NR & (1) (2) (3) & $89.2 \pm 25.2$ & 8 \\
\hline $\begin{array}{l}\text { Kaufman et al. (1997) } \\
\text { [42] }\end{array}$ & Retrospective & NR & $\begin{array}{l}\text { United States } \\
\text { (America) }\end{array}$ & HR-HPV & NR & (1) (3) & 6 & 7 \\
\hline $\begin{array}{l}\text { Campion et al. (1986) } \\
\text { [43] }\end{array}$ & Prospective & $<30$ & $\begin{array}{l}\text { Britain } \\
\text { (Europe) }\end{array}$ & NR & NR & (1) (2) (3) & $\begin{array}{c}22.4 \\
(19-30)\end{array}$ & 7 \\
\hline
\end{tabular}

Note. (1): the relative risk (RR) of progression of CIN1 patients of HPV-positive compared with the HPV-negative; (2): the relative risk (RR) of persistence of CIN1 patients of HPV-positive compared with the HPV-negative; (3): the relative risk (RR) of regression of CIN1 patients of HPV-positive compared with the HPV-negative. HPV, human papillomavirus; HR-HPV, high-risk HPV; LR-HPV, low-risk HPV; HPV(+), HPV-positive; NR, not reported.

TABLE 2: The influence of HR-HPV infection time on CIN1 lesions.

\begin{tabular}{|c|c|c|c|c|c|c|c|}
\hline \multirow{2}{*}{ Disease outcome } & \multirow{2}{*}{ Infection time } & \multirow{2}{*}{ Number of studies } & \multicolumn{3}{|c|}{ Heterogeneity test results } & \multirow{2}{*}{ Merged effect RR value (95\% CI) } & \multirow{2}{*}{$P$ value } \\
\hline & & & $Q$ Value & $P$ Value & $I^{2}(\%)$ & & \\
\hline \multirow{2}{*}{ Progression } & Persistent & 3 & 2.49 & 0.290 & 20 & $13.91(3.46,55.90)$ & 0.000 \\
\hline & Transient & 2 & 0.05 & 0.820 & 0 & $1.06(0.12,9.01)$ & 0.960 \\
\hline \multirow{2}{*}{ Persistent } & Persistent & 2 & 0.22 & 0.640 & 0 & $2.15(0.75,6.18)$ & 0.160 \\
\hline & Transient & 2 & 0.02 & 0.890 & 0 & $0.57(0.17,1.92)$ & 0.360 \\
\hline \multirow{2}{*}{ Regression } & Persistent & 2 & 1.86 & 0.170 & 46 & $0.61(0.47,0.80)$ & 0.000 \\
\hline & Transient & 2 & 0.22 & 0.640 & 0 & $1.03(0.86,1.24)$ & 0.750 \\
\hline
\end{tabular}

$\mathrm{RR}$, relative risk; CI, confidence interval.

$\left(P<0.00001 ; I^{2}=76 \%\right.$; Figure 2(b)). Twenty-seven studies estimated the impact of HPV infection on the regression of CIN1 lesions; pooled analysis showed that the ratio of CIN1 disease regression was 0.65 -fold lower in the HPV-positive group than in the HPV-negative group (95\% CI: 0.59-0.71; $Z=9.39 ; P<0.00001)$, with high heterogeneity $(P=0.0003$; $I^{2}=55 \%$; Figure 2(c)).

In subgroup analyses, the risk of the persistence of CIN1 was higher in American than European or Asian populations $\left(\mathrm{RR}_{\text {Asian }}=1.54,95 \% \mathrm{CI}: 1.17-2.02 ; \mathrm{RR}_{\text {European }}=0.97\right.$, 95\%CI: 0.73-1.30; $\mathrm{RR}_{\text {American }}=2.29$, 95\%CI: $1.59-3.28 ; P=$ $0.001)$. The ratio of regression of CIN1 was higher in patients followed up for 18-24 months than in those followed up for 6-18 months or $>24$ months $\left(\mathrm{RR}_{6-18}=0.61,95 \% \mathrm{CI}\right.$ : $0.53-0.70 ; \mathrm{RR}_{18-24}=0.73,95 \% \mathrm{CI}: 0.67-0.80 ; \mathrm{RR}_{>24}=0.55$, 95\% CI: $0.46-0.66 ; P=0.007)$. Significant differences in HPV type, study design, and sample size were not detected (see Appendix 4).

4.2. The Influence of HR-HPV Infection Time on CIN1 Lesions. Long or short HR-HPV infection times had different effects on CIN1 lesion history. Persistent HR-HPV infection means that, in two or more times, the HR-HPV detected was positive and transient HR-HPV infection means that, in only one time, the HR-HPV detected was positive [6]. The risk of CIN1 disease progression was 13.91-fold higher in the persistent HR-HPV infection group than in the HPV-negative group (95\% CI: 3.46-55.90; $P=0.000$ ); the ratio of CIN1 disease regression was 0.61-fold lower in the persistent HR-HPV infection group than in the HPV-negative group (95\% CI: $0.47-0.80 ; P=0.000)$. The impact of transient HR-HPV infection on CIN1 disease progression and regression was not statistically significant. Furthermore, persistent and transient $\mathrm{HPV}$ infection did not have a significant impact on CIN1 persistence (Table 2).

4.3. Sensitivity Analysis. We conducted a sensitivity analysis for the progression, persistence, and regression of CIN1 disease, respectively (see Appendix 5). All of the included studies were distributed evenly from the central line, with no significant deviation. Therefore, no individual study affected the pooled effect results. 


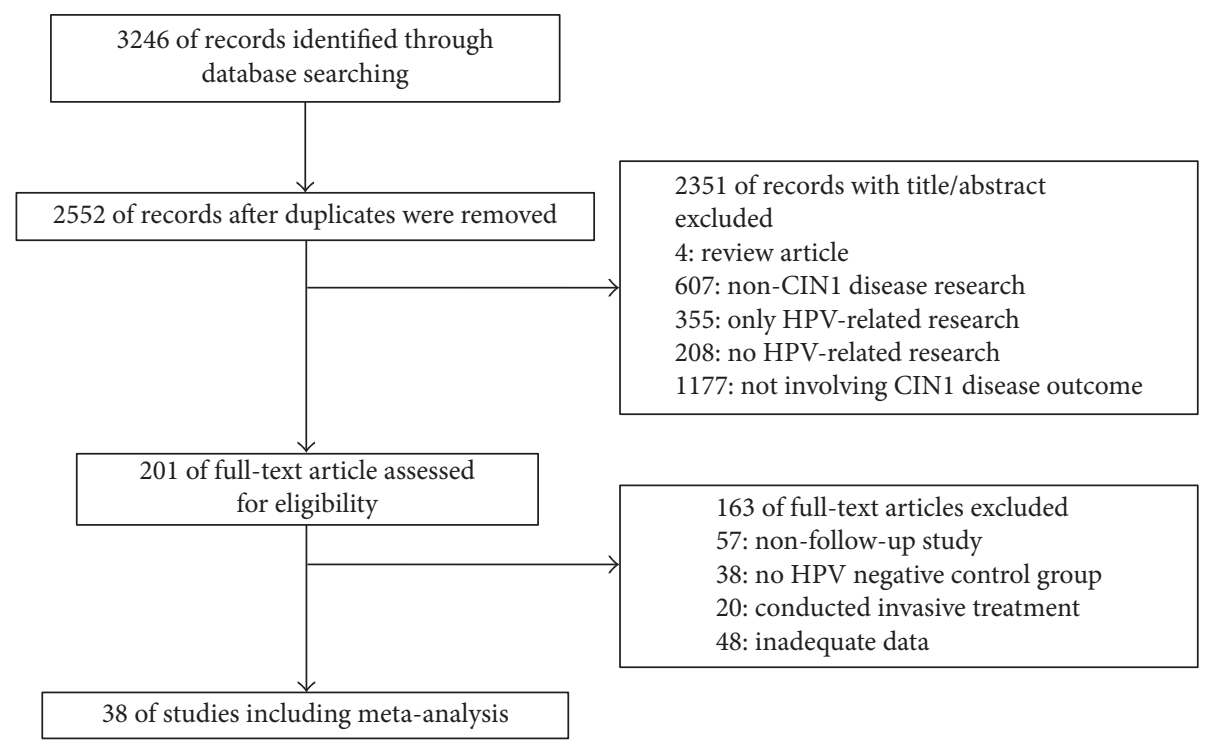

FIGURE 1: Flowchart of identifying and including studies.

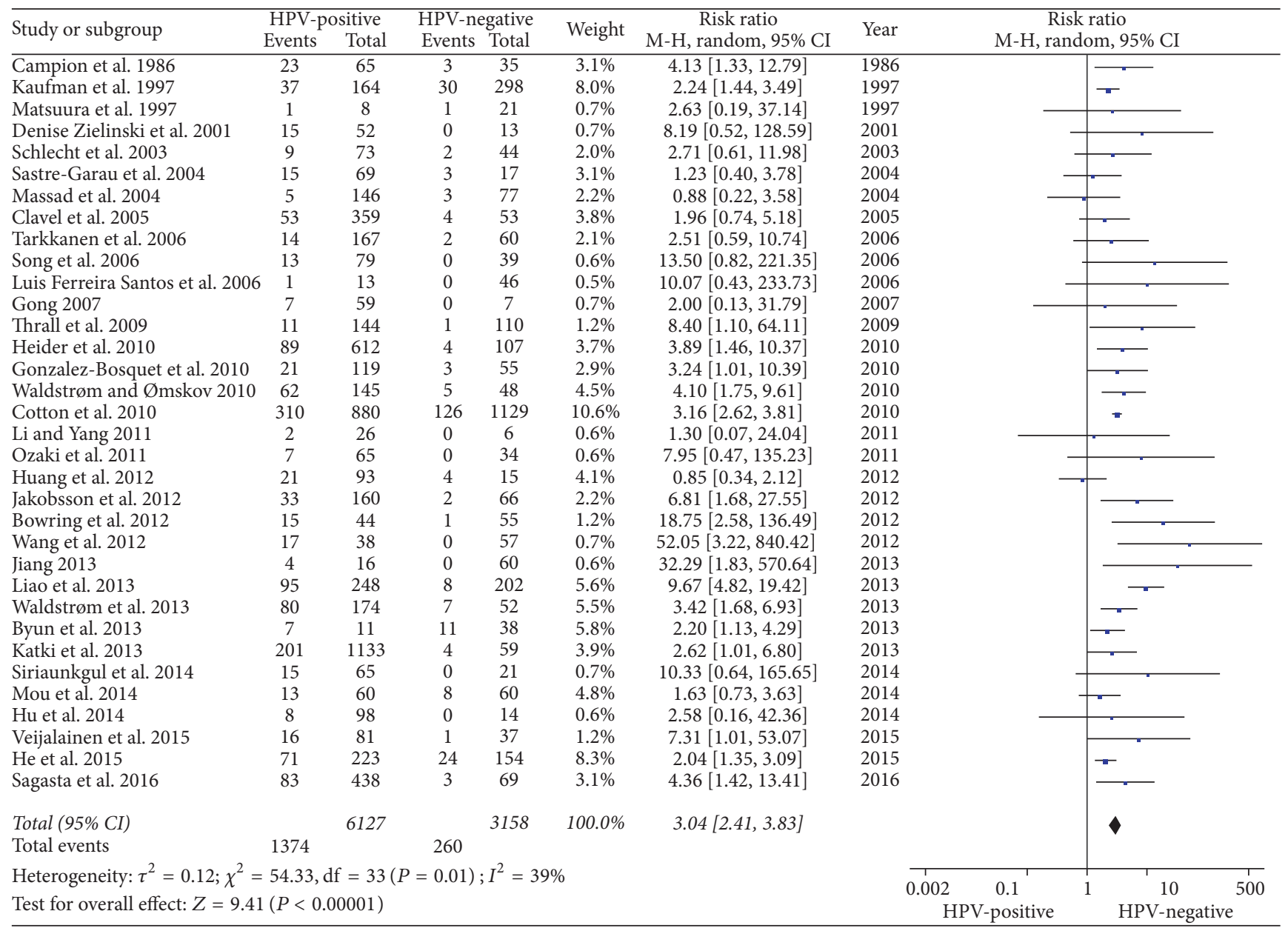

(a)

Figure 2: Continued. 


\begin{tabular}{|c|c|c|c|c|c|c|c|c|c|c|}
\hline \multirow{2}{*}{ Study or subgroup } & \multicolumn{2}{|c|}{ HPV-positive } & \multicolumn{2}{|c|}{ HPV-negative } & \multirow{2}{*}{ Weight } & \multirow{2}{*}{$\begin{array}{c}\text { Risk ratio } \\
\mathrm{M}-\mathrm{H}, \text { random, } 95 \% \text { CI }\end{array}$} & \multirow{2}{*}{ Year } & \multirow{2}{*}{\multicolumn{2}{|c|}{$\begin{array}{c}\text { Risk ratio } \\
\mathrm{M}-\mathrm{H}, \text { random, } 95 \% \text { CI }\end{array}$}} & \\
\hline & Events & Total & Events & Total & & & & & & \\
\hline Sagasta et al. 2016 & 128 & 438 & 17 & 69 & $5.7 \%$ & $1.19[0.77,1.84]$ & 2016 & & 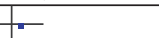 & \\
\hline He et al. 2015 & 58 & 223 & 25 & 154 & $5.7 \%$ & $1.60[1.05,2.44]$ & 2015 & & $\longleftarrow$ & \\
\hline Siriaunkgul et al. 2014 & 25 & 65 & 9 & 21 & $4.9 \%$ & $0.90[0.50,1.61]$ & 2014 & 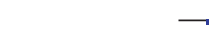 & - & \\
\hline Mou et al. 2014 & 32 & 60 & 21 & 60 & $5.8 \%$ & $1.52[1.00,2.32]$ & 2014 & & . & \\
\hline Hu et al. 2014 & 11 & 98 & 1 & 14 & $1.2 \%$ & $1.57[0.22,11.26]$ & 2014 & & & \\
\hline Jiang 2013 & 9 & 16 & 10 & 60 & $4.3 \%$ & $3.38[1.66,6.88]$ & 2013 & & & \\
\hline Katki et al. 2013 & 434 & 1133 & 12 & 59 & $5.3 \%$ & $1.88[1.13,3.14]$ & 2013 & & 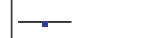 & \\
\hline Waldstrøm et al. 2013 & 66 & 174 & 31 & 52 & $6.3 \%$ & $0.64[0.47,0.85]$ & 2013 & $\mp$ & & \\
\hline Bowring et al. 2012 & 20 & 44 & 26 & 55 & $5.7 \%$ & $0.96[0.63,1.47]$ & 2012 & & + & \\
\hline Li and Yang 2011 & 11 & 26 & 1 & 6 & $1.3 \%$ & $2.54[0.40,16.06]$ & 2011 & & & \\
\hline Waldstrøm and Ømskov 2010 & 63 & 145 & 28 & 48 & $6.3 \%$ & $0.74[0.55,1.01]$ & 2010 & - & & \\
\hline Heider et al. 2010 & 357 & 612 & 44 & 107 & $6.6 \%$ & $1.42[1.12,1.80]$ & 2010 & & - & \\
\hline Thrall et al. 2009 & 54 & 144 & 12 & 110 & $5.0 \%$ & $3.44[1.94,6.10]$ & 2009 & & & \\
\hline Gong 2007 & 20 & 59 & 2 & 7 & $2.4 \%$ & $1.19[0.35,4.04]$ & 2007 & & & \\
\hline Song et al. 2006 & 16 & 79 & 6 & 39 & $3.7 \%$ & $1.32[0.56,3.10]$ & 2006 & & & \\
\hline Luis Ferreira Santos et al. 2006 & 8 & 13 & 7 & 46 & $3.9 \%$ & $4.04[1.81,9.06]$ & 2006 & & & \\
\hline Clavel et al. 2005 & 72 & 359 & 3 & 53 & $2.7 \%$ & $3.54[1.16,10.84]$ & 2005 & & & \\
\hline Sastre-Garau et al. 2004 & 22 & 69 & 5 & 17 & $3.8 \%$ & $1.08[0.48,2.44]$ & 2004 & & & \\
\hline Alameda et al. 2004 & 10 & 18 & 5 & 17 & $3.7 \%$ & $1.89[0.81,4.39]$ & 2004 & & & \\
\hline Massad et al. 2004 & 104 & 146 & 31 & 77 & $6.4 \%$ & $1.77[1.32,2.37]$ & 2004 & & 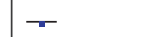 & \\
\hline Denise Zielinski et al. 2001 & 23 & 52 & 6 & 13 & $4.5 \%$ & $0.96[0.49,1.86]$ & 2001 & & - & \\
\hline Matsuura et al. 1997 & 7 & 8 & 3 & 21 & $2.8 \%$ & $6.13[2.08,18.03]$ & 1997 & & & \\
\hline Campion et al. 1986 & 3 & 65 & 4 & 35 & $1.9 \%$ & $0.40[0.10,1.70]$ & 1986 & & - & \\
\hline Total (95\% CI) & & 4046 & & 1140 & $100.0 \%$ & $1.48[1.17,1.87]$ & & & $>$ & \\
\hline Total events & 1553 & & 309 & & & & & & & \\
\hline Heterogeneity: $\tau^{2}=0.21 ; \chi^{2}=$ & $=92.12$ & $f=22$ & $<0.00$ & $01) ; I^{2}$ & $=76 \%$ & & 0.01 & 0.1 & 10 & 100 \\
\hline Test for overall effect: $Z=3.25$ & $5(P=0$ & $01)$ & & & & & & HPV-positive & HPV-neg & \\
\hline
\end{tabular}

(b)

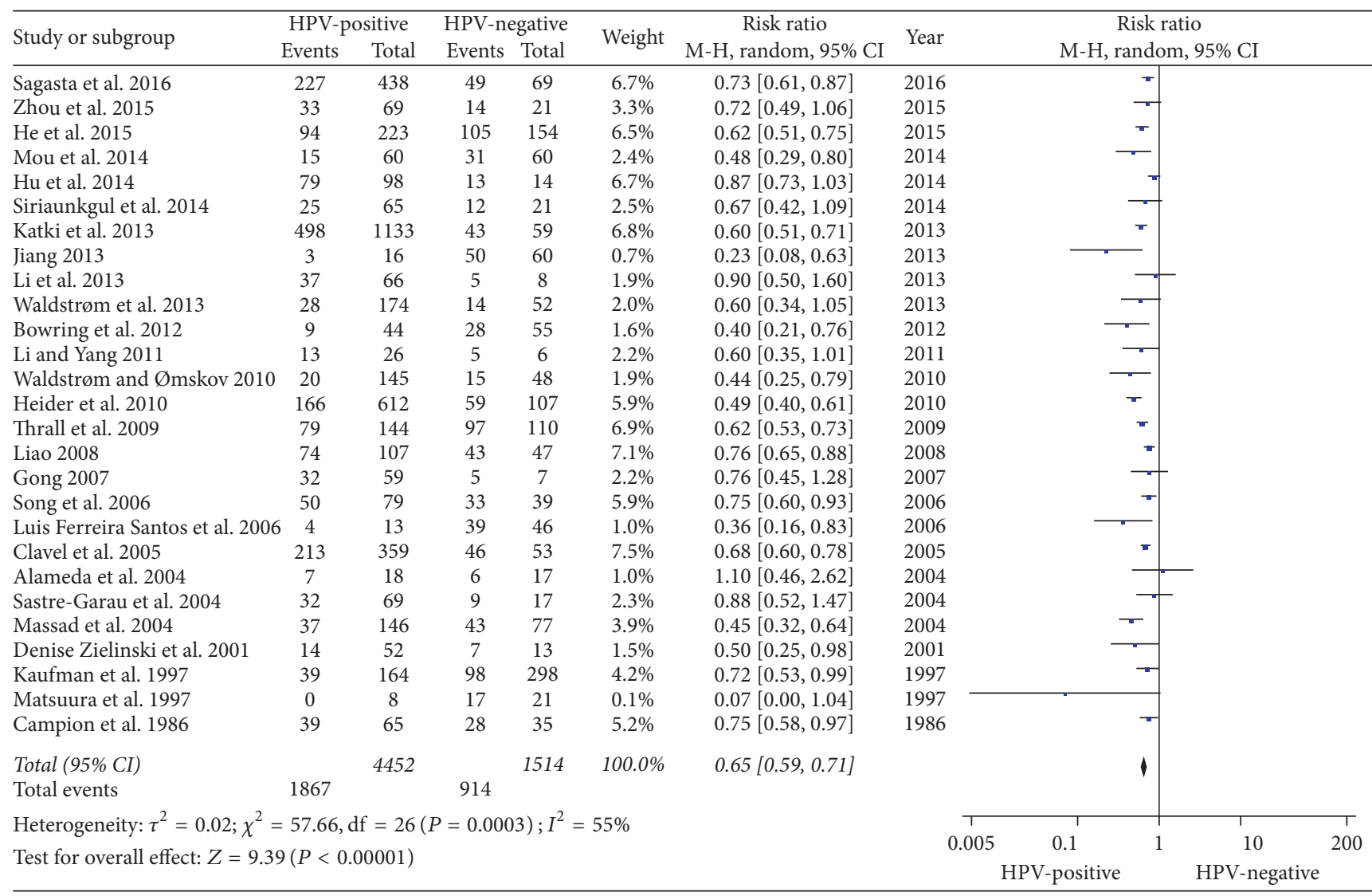

(c)

FIGURE 2: Forest plot of HPV-positive patients and CIN1 disease outcomes. HPV positivity in the exposed group and HPV negativity in the control group. (a) Forest plot of HPV positivity and CIN1 disease progression; (b) Forest plot of HPV positivity and CIN1 disease persistence; (c) Forest plot of HPV positivity and CIN1 disease regression. 


\section{Discussion}

A total of 38 studies were included in the current study. Of these, 23 studies examined HR-HPV infections and three of these also considered LR-HPV infection. Three studies assessed HPV infection times. Studies have shown that HPV infections are associated with an extended disease course in CIN1, increasing the risk of disease progression and hampering the reversal of CIN1. Persistent HR-HPV infection was a major factor associated with CIN1 progression. This finding provides important data for the clinical management of CIN1 disease, in order to avoid excessive or inadequate treatment. Regional population distribution and follow-up time were also associated with CIN1 disease outcome.

In the HPV-positive group, the risks of CIN1 progression, persistence, and regression, respectively, were 3.02, 1.45, and 0.65 , compared to the HPV-negative group. A randomized controlled study from the atypical squamous cells of undetermined significance-low-grade squamous intraepithelial lesion (ASCUS-LSIL) (ALTS) group [45] reported higher risks of CIN1 progression and persistence (12.34 and 2.41, resp.) in the HPV-positive group than that observed in our study. The ratio of CIN1 regression in the HPV-positive group was 0.19 , which is lower than that found in this study. These findings may be explained by the fact that $34.2 \%$ of the included studies involved population-based screening and identification of patients with CIN1 was the object of study. Compared to the ALTS study, with subjects from four large clinical centers, the patient's condition is relatively severe. However, this study reached a comparable conclusion. HPV positivity was associated with hampered CIN1 lesion regression and increased risk of disease progression and persistence.

Our research on the impact of HPV type and infection duration on CIN1 disease history found that persistent HR$\mathrm{HPV}$ infection was a major risk factor for CIN1 progression to CIN2+, while LR-HPV and transient infections were not significantly associated with increased risk of CIN1 progression. The results are corroborated in a large prospective study by Dalstein et al. [46]. Furthermore, only Huang et al. [23] explored the relationship between human papillomavirus type 16 (HPV16), HPV18, and other oncogenic HPV and CIN1 disease, reporting that the risk of CIN1 progression to $\mathrm{CIN} 2 / 3$ in patients with HPV16 infection was 2.51 and 6.95 times that in patients with HPV18 infection and other oncogenic forms, respectively. HPV16 is considered the major risk factor for CIN1 disease progression.

Regional population distribution and follow-up time were the two main factors influencing CIN1 disease history. The risk of disease progression in HPV-positive CIN1 patients in the Americas was lower than that of patients in Asian and European countries $\left(\mathrm{RR}_{\text {Asian }}=3.94 ; \mathrm{RR}_{\text {European }}=3.10\right.$; $\left.\mathrm{RR}_{\text {American }}=2.31 ; P=0.380\right)$, and the ratios of disease regression $\left(\mathrm{RR}_{\text {Asian }}=1.54 ; \mathrm{RR}_{\text {European }}=0.97 ; \mathrm{RR}_{\text {American }}=\right.$ $2.29 ; P=0.001)$ and persistence $\left(\mathrm{RR}_{\text {Asian }}=0.70 ; \mathrm{RR}_{\text {European }}=\right.$ $0.69 ; \mathrm{RR}_{\text {American }}=0.56 ; P=0.060$ ) were higher than those in Asia and European countries. In these Americas countries, 87.5\% are North Americas countries (seven US and one
Brazilian states). Previous studies have shown that a screening strategy of ThinPrep cytologic tests (TCTs) combined with HPV tests has gained popularity [43]. CIN1 had a lower probability of progression to invasive cervical cancer (ICC) and a higher probability of regression. In some Asian and European countries, screening is performed mainly by visual inspection with acetic acid or iodine and Pap smears. These methods are less costly than TCT and HPV DNA tests [47]. Therefore, the probability of CIN1 progression was relatively high and the probability of disease reversal was relatively low. Numerous studies have shown gradual CIN1 regression with clearance of HPV infections, and our study found that natural clearance of HPV infections may take longer than 24 months. This is consistent with the interval of two years or longer for HPV-based cervical cancer screening [4850].

This study has the following advantages. First, the welldesigned studies provided strong evidence for the analysis of the influence of HPV infection on CIN1 disease history. Furthermore, the full search was relatively comprehensive and included a large number of studies, significantly increasing the sample size compared with using the single original research study criteria; therefore, the combined effect size was more accurate. Second, subgroup analyses were performed according to HPV type, study design, regional population distribution, sample size, and follow-up time, in order to explore potential confounders. Some limitations should be considered when interpreting the results of this study. First, CIN1 is affected by many factors and we were unable to control for parameters such as age at first sexual intercourse, number of pregnancies and delivery times, and individual immune status. Second, most studies included a larger age range; therefore, we did not conduct subgroup analysis by patient age. Third, more papers from China were included in the present study, which would limit the significance. This conclusion needs to be further testified in the people from other countries. Finally, there are few studies on low-risk HPV infection potentially affecting the results of subgroup analysis of HPV type. Therefore, we will research low-risk $\mathrm{HPV}$ infection in future studies to improve the accuracy of these results.

\section{Conclusion}

HPV infection resulted in an increased risk of CIN1 progression and reducing disease reversibility. Persistent high-risk $\mathrm{HPV}$ infection resulted in a further increased risk of CIN1 progression. Furthermore, regional population distribution and follow-up times influenced CIN1 disease history.

\section{Disclosure}

The funders had no role in study design, data collection and analysis, decision to publish, or preparation of the manuscript.

\section{Conflicts of Interest}

The authors have declared that no conflicts of interest exist. 


\section{Authors' Contributions}

Mingzhu Liu performed the data analysis and drafted the manuscript. Mingxia Jing and Shugang Li conceived and designed the study and led the writing of the paper. Mingzhu Liu and Xiaolong Yan jointly developed the search strategy for this study and assessed the titles and abstracts for their relevance to this study. Mingzhu Liu, Xiaolong Yan, Mei Zhang, and Xiaoju Li assessed full articles for inclusion. Mingxia Jing resolved disagreements between authors. All authors read and approved the final manuscript. Mingzhu Liu and Xiaolong Yan contributed equally to this work and should be considered co-first authors.

\section{Acknowledgments}

The authors acknowledge funding from the Science and Technology Plan Project of Xinjiang Production and Construction Corps (no. 2013BB015).

\section{References}

[1] C. H. Gong, The Study of Multi-Monitor Methods on the Natural Prognosis and Intervention Treatment of Cervical Intraepithelial Neoplasiai, Medical School of Nanchang University, Nanchang University, 2007.

[2] X. Xie and W. L. Gou, Obstetrics and Gynecology. 8 version, People's Health Publishing House, Beijing, China, 2013.

[3] Y. J. Feng, “Cervical intraepithelial neoplasia," Journal of Practical Oncology, vol. 18, no. 3, pp. 169-171, 2003.

[4] X. Rong, L. N. Wu, J. Y. Gao et al., "Study of natural history of cervical intraepithelial neoplasia gradeI," Progress in Obstetrics and Gynecology, vol. 21, no. 5, pp. 365-368, 2012.

[5] R. L. Li and Y. Yang, "Clinical study of cervical HPV infection and the prognosis of cervical intraepithelial neoplasia I," Health Research, vol. 31, no. 2, pp. 97-99, 2011.

[6] H. H. Wang, L. Chen, M. Chen, L. L. Wu, and J. P. Li, "Significance of high risk human papillomavirus monitoring in follow-up of cervical intraepithelial neoplasia?" Maternal and Child Health Care of China, vol. 27, no. 6, pp. 820-822, 2012.

[7] M. J. Thrall, D. A. Smith, and D. R. Mody, "Women $\geq 30$ years of age with low grade squamous intraepithelial lesion (LSIL) have low positivity rates when cotested for high-risk human papillomavirus: Should we reconsider HPV triage for LSIL in older women?" Diagnostic Cytopathology, vol. 38, no. 6, pp. 407412, 2010.

[8] A. B. Mill, "The natural history of cervical cancer and the implications for screening policy," in Genevao World Health Organization Geneve. Cervical cancer screening programmes, pp. 6-14, 1992.

[9] S. K. Kjaer, "Risk factors for cervical neoplasia in Denmark," APMIS, vol. 80, pp. 1-41, 1998.

[10] A. Sagasta, P. Castillo, A. Saco et al., "P16 staining has limited value in predicting the outcome of histological low-grade squamous intraepithelial lesions of the cervix," Modern Pathology, vol. 29, no. 1, pp. 51-59, 2016.

[11] O. Veijalainen, S. Tuomisaari, T. Luukkaala, and J. Mäenpää, "High risk HPV testing in the triage of repeat ASC-US and LSIL," Acta Obstetricia et Gynecologica Scandinavica, vol. 94, no. 9, pp. 931-936, 2015.
[12] X. He, H. C. Tao, S. Z. Wang et al., "An analysis of high-risk human papillomavirus DNA-negative cervical intraepithelial neoplasia in atypical squamous cells of undetermined significance and low-grade squamous intraepithelial lesion smears: a retrospective study," Journal of Capital Medical University, vol. 36, no. 2, pp. 205-211, 2015.

[13] Y. H. Zhou, W. F. Fan, Y. Q. Huang, J. J. Dong, and H. Y. Guo, "Combined detection of high-risk human papillomavirus and telomerase gene amplification in a mild cervical intraepithelial neoplasia shunt management role," Journal of Xinxiang Medical University, vol. 32, no. 11, pp. 1032-1035, 2015.

[14] L. Mou, Y. Hu, Y. Lan, and F. L. Lv, "Correlative research of HPV infection and the disease progression of cervical intraepithelial neoplasia," Chongqing Medicine, vol. 43, no. 29, pp. 3895-3896, 2014.

[15] S. Siriaunkgul, J. Settakorn, K. Sukpan et al., "Populationbased cervical cancer screening using high-risk HPV DNA test and liquid-based cytology in northern Thailand," Asian Pacific Journal of Cancer Prevention, vol. 15, no. 16, pp. 6837-6842, 2014.

[16] S. Y. Hu, F. H. Zhao, J. F. Ma et al., "A prospective study on the prognosis of biopsy.confirmed cervical intraepithelial neoplasia grade 1 and the relationship witlI higII-risk human papiliomavirus," Chinese Journal of Preventive Medicine, vol. 48, no. 5, pp. 361-365, 2014.

[17] H. Jiang, "The impact of high-risk HPV infection and follow-up on the prognosis of CINI,' International Journal of Gynecology \& Obstetrics, vol. 40, no. 4, pp. 324-326, 2013.

[18] M. Waldstrøm, R. K. Christensen, and D. Ornskov, "Evaluation of p16INK4a/Ki-67 dual stain in comparison with an mRNA human papillomavirus test on liquid-based cytology samples with low-grade squamous intraepithelial lesion," Cancer Cytopathology, vol. 121, no. 3, pp. 136-145, 2013.

[19] H. A. Katki, M. Schiffman, P. E. Castle et al., "Five-year risks of CIN 3+ and cervical cancer among women who test papnegative but are HPV-positive," Journal of Lower Genital Tract Disease, vol. 17, no. 5, supplement 1, pp. S56-S63, 2013.

[20] S. W. Byun, A. Lee, S. Kim, Y. J. Choi, Y. S. Lee, and J. S. Park, "Immunostaining of p16INK4a/Ki-67 and L1 capsid protein on liquid-based cytology specimens obtained from ASC-H and LSIL-H cases," International Journal of Medical Sciences, vol. 10, no. 12, pp. 1602-1607, 2013.

[21] G.-D. Liao, J. W. Sellors, H.-K. Sun et al., "P16INK4A immunohistochemical staining and predictive value for progression of cervical intraepithelial neoplasia grade 1: a prospective study in China," International Journal of Cancer, vol. 134, no. 7, pp. 17151724, 2014.

[22] L. Li, W. Jiang, S. Y. Zeng, and L. Y. Li, "Prospective study of human telomerase ribonucleic acid component gene detection by fluorescence in situ hybridization in predicting natural prognosis of cervical intraepithelial neoplasia 1," Chinese Journal of Clinical Oncology, vol. 40, no. 1, pp. 25-28, 2013.

[23] L.-W. Huang, Y.-H. Lin, H.-S. Pan, K.-M. Seow, and C.-Y. Lin, "Human papillomavirus genotyping as a predictor of highgrade cervical dysplasia in women with mildly cytologic abnormalities: a two-year follow-up report," Diagnostic Cytopathology, vol. 40, no. 8, pp. 673-677, 2012.

[24] J. Bowring, R. Albrow, A. Fisher et al., "A prospective study of human papillomavirus (HPV) testing to resolve uncertainty in colposcopy," Cytopathology, vol. 24, no. 5, pp. 309-313, 2013.

[25] M. Jakobsson, J. Tarkkanen, E. Auvinen, R. Häkkinen, P. Laurila, and A. M. Tapper, "Colposcopy referral rate can be reduced by high-risk human papillomavirus triage in the management of 
recurrent atypical squamous cells of undetermined significance or low-grade squamous intraepithelial lesion cytology in Finland," International Journal of STD and AIDS, vol. 23, no. 7, pp. 485-489, 2012.

[26] S. Ozaki, Y. Zen, and M. Inoue, "Biomarker expression in cervical intraepithelial neoplasia: Potential progression predictive factors for low-grade lesions," Human Pathology, vol. 42, no. 7, pp. 1007-1012, 2011.

[27] E. Gonzalez-Bosquet, L. Selva, and J. Sabria, "Predictive factors for the detection of CINII-III in the follow-up of women with CIN I," European Journal of Gynaecological Oncology, vol. 31, no. 4, pp. 369-71, 2010.

[28] M. Waldstrøm and D. Ømskov, "Clinical performance of a human papillomavirus messenger RNA test (Aptima HPV Assay)on residual material from archived 3-year-old PreservCyt samples with low-grade squamous intraepithelial lesion," Archives of Pathology and Laboratory Medicine, vol. 135, no. 8, pp. 1052-1056, 2011.

[29] A. Heider, R. M. Austin, and C. Zhao, "HPV test results stratify risk for histopathologic follow-up findings of high-grade cervical intra-epithelial neoplasia in women with low-grade squamous intra-epithelial lesion pap results," Acta Cytologica, vol. 55, no. 1, pp. 48-53, 2010.

[30] S. Cotton, L. Sharp, J. Little et al., "The role of human papillomavirus testing in the management of women with low-grade abnormalities: multicentre randomised controlled trial," BJOG, vol. 117, no. 6, pp. 645-659, 2010.

[31] G. D. Liao, "Prevalence of P161NK4a expression in cervical histology and predictive validity of P161NK4a in cervical intraepithelial neoplasia grade 1 transformation," Journal of Chongqing Medical University, 2008.

[32] A. Luis Ferreira Santos, S. Françoise Mauricette Derchain, L. Otávio Sarian, M. Roberto Martins, S. Siani Morais, and K. Juhani Syrjänen, "Performance of Pap smear and human papilloma virus testing in the follow-up of women with cervical intraepithelial neoplasia grade 1 managed conservatively," Acta Obstetricia et Gynecologica Scandinavica, vol. 85, no. 4, pp. 444450, 2006.

[33] J. Tarkkanen, E. Auvinen, P. Nieminen et al., "HPV DNA testing as an adjunct in the management of patients with low grade cytological lesions in Finland," Acta Obstetricia et Gynecologica Scandinavica, vol. 86, no. 3, pp. 367-372, 2007.

[34] S.-H. Song, J.-K. Lee, M.-J. Oh, J.-Y. Hur, Y.-K. Park, and H.-S. Saw, "Risk factors for the progression or persistence of untreated mild dysplasia of the uterine cervix," International Journal of Gynecological Cancer, vol. 16, no. 4, pp. 1608-1613, 2006.

[35] C. Clavel, J.-P. Bory, S. Caudroy et al., "Usefulness of HPV testing in the follow-up of untreated cervical low grade lesions," Histology and Histopathology, vol. 20, no. 4, pp. 1085-1091, 2005.

[36] L. S. Massad, C. T. Evans, H. Minkoff et al., "Natural history of grade 1 cervical intraepithelial neoplasia in women with human immunodeficiency virus," Obstetrics and Gynecology, vol. 104, no. 5, part 1, pp. 1077-1085, 2004.

[37] X. Sastre-Garau, I. Cartier, N. Jourdan-Da Silva, P. De Crémoux, V. Lepage, and D. Charron, "Regression of low-grade cervical intraepithelial neoplasia in patients with HLA-DRB1*13 genotype," Obstetrics and Gynecology, vol. 104, no. 4, pp. 751-755, 2004.

[38] F. Alameda, P. Fuste, S. Boluda et al., "The Ki-67 labeling index is not a useful predictor for the follow-up of cervical intraepithelial neoplasia 1," Journal of Lower Genital Tract Disease, vol. 8, no. 4, pp. 313-316, 2004.
[39] N. F. Schlecht, R. W. Platt, E. Duarte-Franco et al., "Human papillomavirus infection and time to progression and regression of cervical intraepithelial neoplasia," Journal of the National Cancer Institute, vol. 95, no. 17, pp. 1336-1343, 2003.

[40] G. Denise Zielinski, P. J. F. Snijders, L. Rozendaal et al., "Highrisk HPV testing in women with borderline and mild dyskaryosis: long-term follow-up data and clinical relevance," Journal of Pathology, vol. 195, no. 3, pp. 300-306, 2001.

[41] Y. Matsuura, T. Kawagoe, N. Toki, K. Sugihara, and M. Kashimura, "Low grade cervical intraepithelial neoplasia associated with human papillomavirus infection. Long-term followup," Acta Cytologica, vol. 42, no. 3, pp. 625-630, 1998.

[42] R. H. Kaufman, E. Adam, J. Icenogle, and W. C. Reeves, "Human papillomavirus testing as triage for atypical squamous cells of undetermined significance and low-grade squamous intraepithelial lesions: sensitivity, specificity, and cost-effectiveness," American Journal of Obstetrics and Gynecology, vol. 177, no. 4, pp. 930-936, 1997.

[43] M. J. Campion, J. Cuzick, D. J. McCance, and A. Singer, "Progressive potential of mild cervical atypia: prospective cytological, colposcopic, and virological study," The Lancet, vol. 328, no. 8501, pp. 237-240, 1986.

[44] X. T. Zeng, H. Liu, X. Chen, and W. D. Leng, "Meta analysis series IV: quality assessment tool for observational research," Chinese Journal of Evidence-Based Cardiovascular Medicine, vol. 4, no. 4, pp. 297-299, 2012.

[45] ASCUS-LSIL Triage Study (ALTS) Group, "A randomized trial on the management of low-grade squamous intraepithelial lesion cytology interpretations," American Journal of Obstetrics and Gynecology, vol. 188, no. 6, pp. 1393-1400, 2003.

[46] V. Dalstein, D. Riethmuller, J.-L. Préteti et al., "Persistence and load of high-risk HPV are predictors for development of high-grade cervical lesions: a longitudinal French cohort study," International Journal of Cancer, vol. 106, no. 3, pp. 396-403, 2003.

[47] D. Mendes, I. Bains, T. Vanni, and M. Jit, "Systematic review of model-based cervical screening evaluations," BMC Cancer, vol. 15, no. 1, article 334, 2015.

[48] G. Sroczynski, P. Schnell-Inderst, N. Mühlberger et al., "Costeffectiveness of primary HPV screening for cervical cancer in Germany-a decision analysis," European Journal of Cancer, vol. 47, no. 11, pp. 1633-1646, 2011.

[49] S. J. Goldie, J. J. Kim, and T. C. Wright, "Cost-effectiveness of human papillomavirus DNA testing for cervical cancer screening in women aged 30 years or more," Obstetrics and Gynecology, vol. 103, no. 4, pp. 619-631, 2004.

[50] J. J. Kim, M. Brisson, W. J. Edmunds, and S. J. Goldie, "Modeling cervical cancer prevention in developed countries," Vaccine, vol. 26, supplement 10, pp. K76-K86, 2008. 


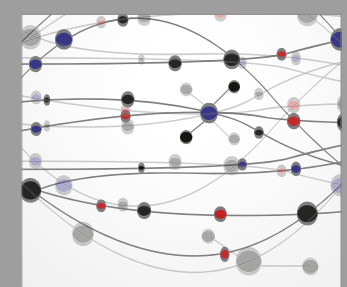

The Scientific World Journal
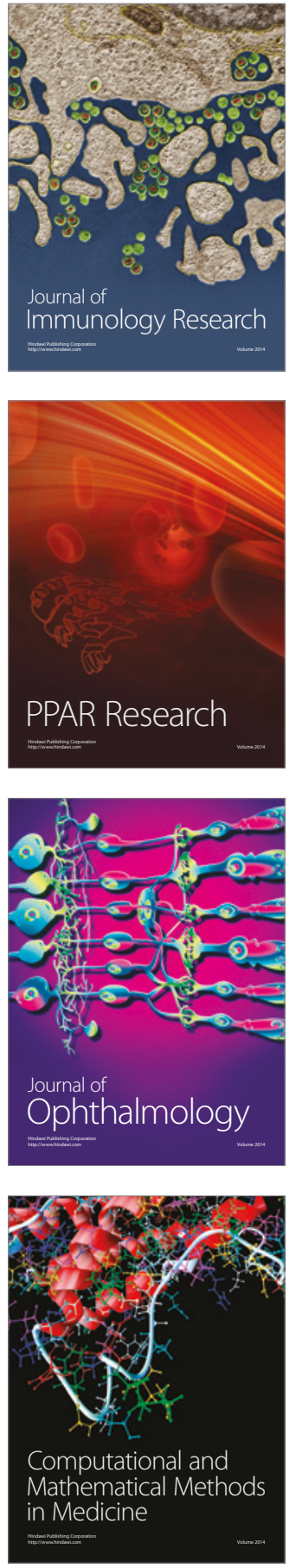

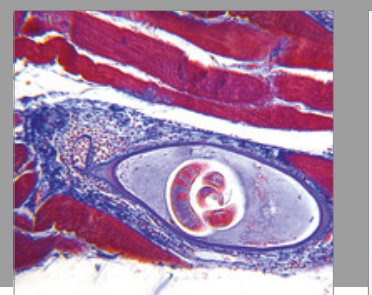

Gastroenterology Research and Practice
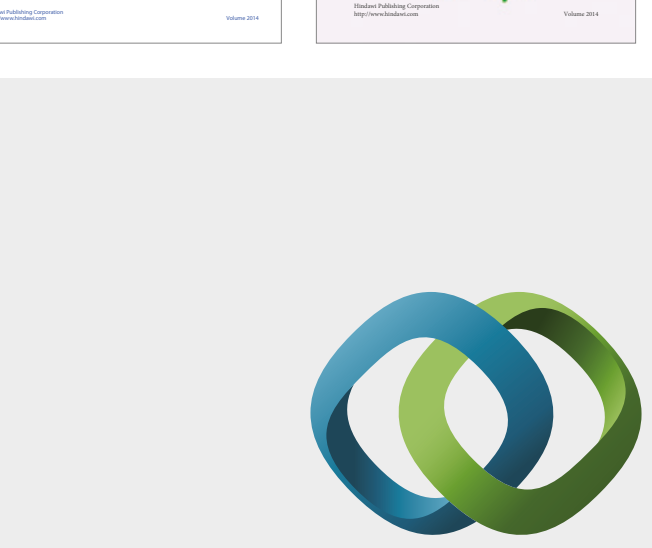

\section{Hindawi}

Submit your manuscripts at

https://www.hindawi.com
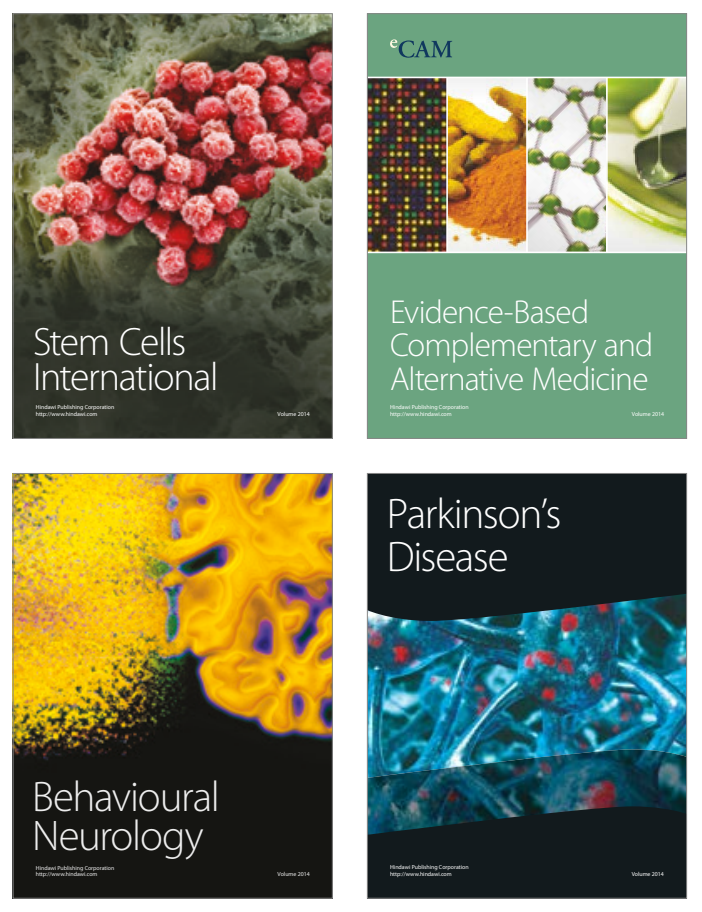
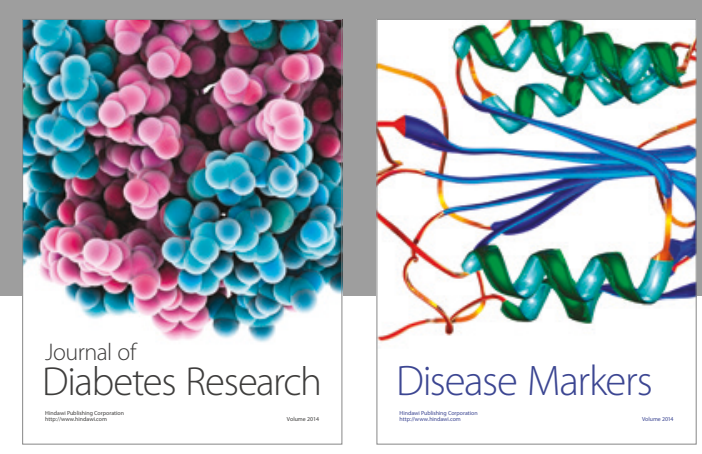

Disease Markers
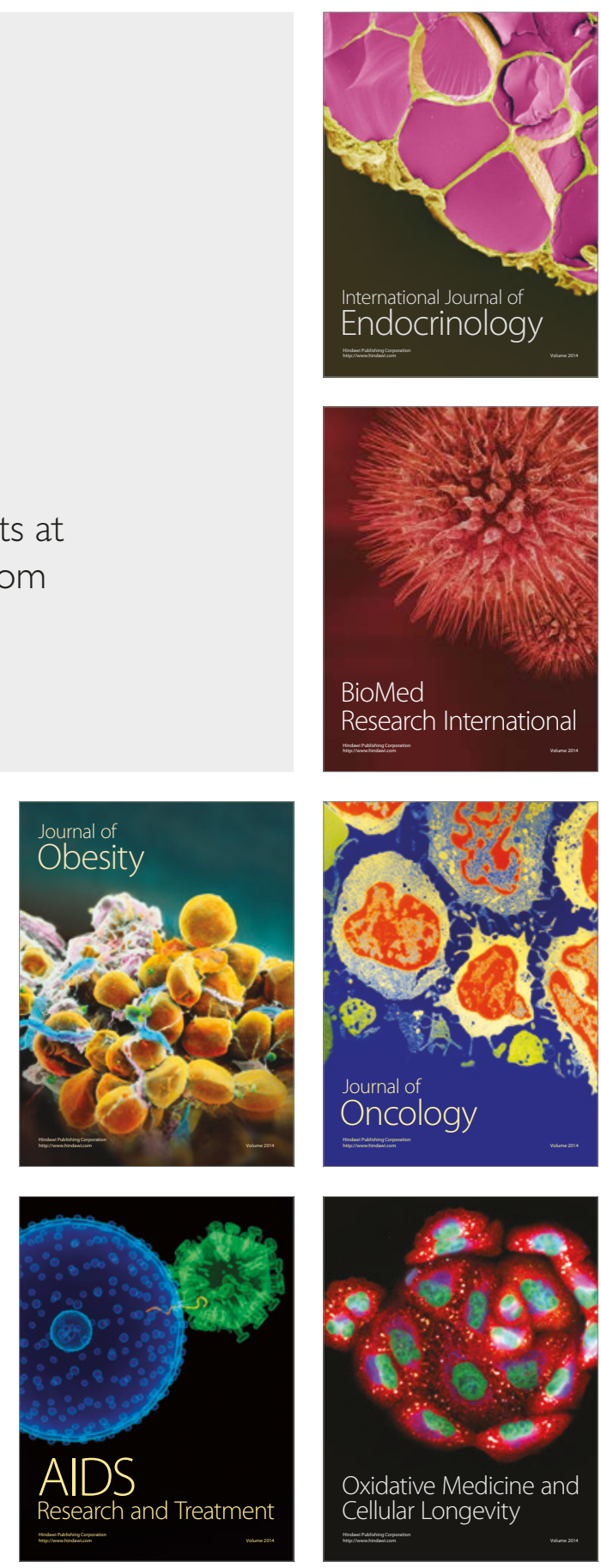